\title{
Zapalenie brzegów powiek - wszechstronne spojrzenie na powszechne schorzenie
}

\author{
Blepharitis: a comprehensive look at a common disease
}

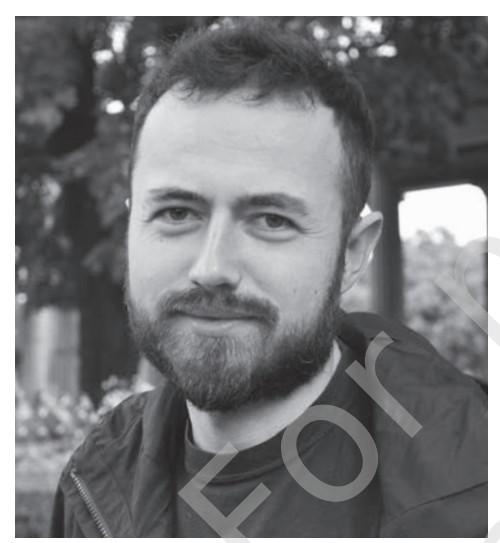

N A JWA ŻN IE J SZE Artykuł omawia zapalenie brzegów powiek w sposób całościowy, ujmuje podział etiopatogenezę, występowanie, diagnostykę, leczenie oraz refleksje autorów w ramach dyskusji.

\section{H I G H L I G H T S}

The article discusses chronic blepharitis in a holistic way, including division, etiopathogenesis, prevalence, diagnostics, treatment, and reflections of the authors in the discussion.

\author{
Michał Karaszewski ${ }^{1,2}$, Marta Misiuk-Hojło ${ }^{1}$,
Joanna Przeździecka-Dołyk ${ }^{1,3}$, Jan Gnus ${ }^{2}$ \\ ${ }^{1}$ Katedra i Klinika Okulistyki, Uniwersytet Medyczny im. Piastów Śląskich we Wrocławiu \\ Kierownik: prof. dr hab. n. med. Marta Misiuk-Hojło \\ Katedra Fizjoterapii, Wydział Nauk o Zdrowiu, Uniwersytet Medyczny im. Piastów Śląskich we Wrocławiu \\ Kierownik: dr hab. n. med. Małgorzata Paprocka-Borowicz, prof. nadzw. \\ ${ }^{3}$ Katedra Optyki i Fotoniki, Wydział Podstawowych Problemów Techniki, Politechnika Wrocławska \\ Kierownik: prof. dr hab. inż. Wacław Urbańczyk
}

\section{STRESZCZENIE}

Zapalenie brzegów powiek to rozpowszechniona na całym świecie, częsta, przewlekła choroba zapalna aparatu ochronnego oczu, której szczegółowa epidemiologia jest trudna do ustalenia. Również rola poszczególnych czynników etiologicznych, takich jak kolonizacja nużeńcem, pozostaje niedookreślona. Rozpoznanie opiera się na wszechstronnym badaniu przedmiotowym w połączeniu z dokładnym badaniem okulistycznym, uzupełnionym o ewentualne badania dodatkowe. Terapia jest długotrwała i zwykle nie prowadzi do pełnego wyleczenia, wymaga od pacjentów cierpliwości i systematycznego zaangażowania. Stale poszerzany wachlarz terapeutyczny pozostaje poza refundacją w ramach publicznej opieki zdrowotnej większości krajów.

Słowa kluczowe: zapalenie brzegów powiek, nużeniec, dysfunkcja gruczołów Meiboma

\section{ABSTRACT}

Chronic blepharitis is a common, chronic inflammatory disease of the external eye whose detailed epidemiology is difficult to determine. Also, the role of individual etiological factors, such as demodex infestation, remains undefined. The diagnosis is based on a comprehensive physical examination with a thorough ophthalmological examination, supplemented with possible additional examinations. The therapy lasts long and usually does not lead to full recovery, requires patience and systematic commitment from patients. The constantly expanding therapeutic range is not reimbursed by public healthcare in most countries.

Key words: chronic blepharitis, Demodex, Meibomian gland dysfunction 


\section{WSTĘP}

Zapalenie brzegów powiek (ZBP) (chronic blepharitis lub lid margin disease) to przewlekły stan zapalny brzegu powiekowego, częsty w populacji ogólnej, szczególnie u osób w średnim i starszym wieku. Powoduje uczucie dyskomfortu i podrażnienia oczu. Słaba zależność między występowaniem objawów podmiotowych i przedmiotowych oraz niejasne mechanizmy procesu chorobowego implikują trudności w postępowaniu leczniczym [1].

\section{PODZIAŁ I ETIOPATOGENEZA}

ZBP dzieli się na tylne, które występuje częściej, oraz przednie. Nierzadko spotyka się postać mieszaną [1].

\section{Tylne zapalenie brzegów powiek}

Zapalenie tylne wiąże się z zaburzeniem funkcji (niewydolnością) gruczołów Meiboma (MGD, Meibomian gland dysfunction). Te zmodyfikowane gruczoły łojowe odpowiadają za wydzielanie tłuszczowej składowej filmu łzowego, budującej jego zewnętrzną powłokę, która chroni przed parowaniem wody z głębiej położonej warstwy wodnej.

Ujścia kanalików końcowych wyprowadzających wydzielinę gruczołów Meiboma ułożone są w jednym rzędzie bezpośrednio przed połączeniem śluzówkowo-skórnym, wzdłuż tylnego brzegu powiek. Do ich zaczopowania dochodzi wskutek aktywności bakteryjnych lipaz. Powodują one powstawanie wolnych kwasów tłuszczowych, które podwyższają temperaturowy próg topnienia łoju i, obniżając jego płynność, uniemożliwiają wydalenie go ze światła kanalików gruczołowych. Długotrwała okluzja prowadzi do zapalenia i hiperkeratynizacji nabłonka kanalikowego [2]. Skutkuje to zadrażnieniem powierzchni oka, może też umożliwiać namnażanie się gronkowca złocistego. Niedobór działających jako surfaktant fosfolipidów w filmie łzowym powoduje nadmierne parowanie łez. Dochodzi do wzrostu osmolarności oraz do niestabilności filmu łzowego. Na skutek patologicznej ewaporacji rozwijają się objawy zespołu suchego oka (ZSO) [3]. Schorzenie to dotyczy wielu milionów osób na całym świecie. Niska świadomość społeczna obliguje do nacisku na rozwój edukacji w tym zakresie [2].

Nieleczona niewydolność gruczołów Meiboma może skutkować obniżeniem jakości życia chorego. Przez analogię do jaskry, która nieleczona kończy się postępującą utratą komórek zwojowych i nieodwracalną utratą widzenia - w przypadku MGD brak leczenia może prowadzić do nieodwracalnej atrofii gruczołów i tym samym, na skutek niestabilności filmu łzowego - do trwałego upośledzenia jakości widzenia w postaci aberracji optycznych. Do oceny zaniku gruczołów Meiboma wykorzystuje się nieinwazyjną metodę meibografii w podczerwieni [4]. Tylne zapalenie brzegów powiek, w porównaniu z zapaleniem przednim, postrzega się bardziej jako przetrwały i przewlekły stan za- palny. Ma ono też związek z występowaniem trądziku różowatego skóry oraz towarzyszy występowaniu jęczmieni mnogich lub nawrotowych [1].

\section{Przednie zapalenie brzegów powiek}

Zapalenie przednie dotyczy natomiast okolicy wokół podstawy rzęs i może mieć podłoże gronkowcowe lub łojotokowe. Bywa postrzegane jako stan związany z przewlekłym czynnikiem zakaźnym, tym samym łatwiej niż postać tylna poddający się leczeniu. W przypadku etiologii gronkowcowej za przyczynę zapalenia, w tym występujących u niektórych chorych objawów czerwonego oka i obwodowych nacieków rogówki, przypuszczalnie odpowiada nieprawidłowa odpowiedź komórkowa na składowe ściany komórkowej gronkowca złocistego. Ten rodzaj zapalenia jest częstszy i bardziej nasilony u pacjentów z atopowym zapaleniem skóry. Zapalenie łojotokowe wiąże się natomiast z uogólnionym łojotokowym zapaleniem skóry (w ponad 90\% przypadków), w którym zmiany typowo lokalizują się na owłosionej skórze głowy, fałdach nosowo-wargowych, za uszami lub na mostku [1].

\section{WYSTEPOWANIE}

Choć ZBP jest jednym z najczęstszych schorzeń okulistycznych, to brakuje danych epidemiologicznych na temat zapadalności i chorobowości w określonych populacjach. Badanie ankietowe wykonane wśród okulistów i optometrystów (USA) wykazało częste występowanie blepharitis - u odpowiednio 37\% i 47\% spośród ich pacjentów [5]. Średnia wieku chorych oscyluje w okolicy 50. r.ż. [6], a chorobowość wzrasta z wiekiem $(5,3 \%$ chorych na MGD w grupie aktywnego zawodowo personelu wojskowego [średnia wieku wynosiła 23 lata], w porównaniu z 71,1\% wśród weteranów amerykańskiej armii [średnia wieku to 68 lat]) [7].

Współczynniki chorobowości dla niewydolności gruczołów Meiboma (MGD) kształtują się w światowej literaturze na bardzo różnych poziomach [6], ze wskazaniem na częstsze występowanie w populacjach azjatyckich niż kaukaskich. Duża jest także zmienność w definiowaniu choroby oraz w aspekcie wieku w badanych grupach [8]. Pacjenci cierpiący na MGD i zapalenie łojotokowe są statystycznie starsi [9] niż cierpiący na zapalenie gronkowcowe (ze średnią wieku wynoszącą w tej grupie 42 lata), które występuje też częściej u kobiet (80\% chorych) [10].

\section{CZYNNIKI RYZYKA}

U połowy pacjentów ze stwierdzonym zakażeniem gronkowcowym w ZBP stwierdzano ZSO, natomiast $\mathrm{u}$ 3/4 chorych na ZSO wykazano gronkowcowe zapalenie w obrębie powiek lub spojówek $[10,11]$. 


\section{RYCINA $(1$}

Schemat obrazujący struktury aparatu ochronnego oka. Źródło: materiały własne Joanny Przeździeckiej-Dołyk.
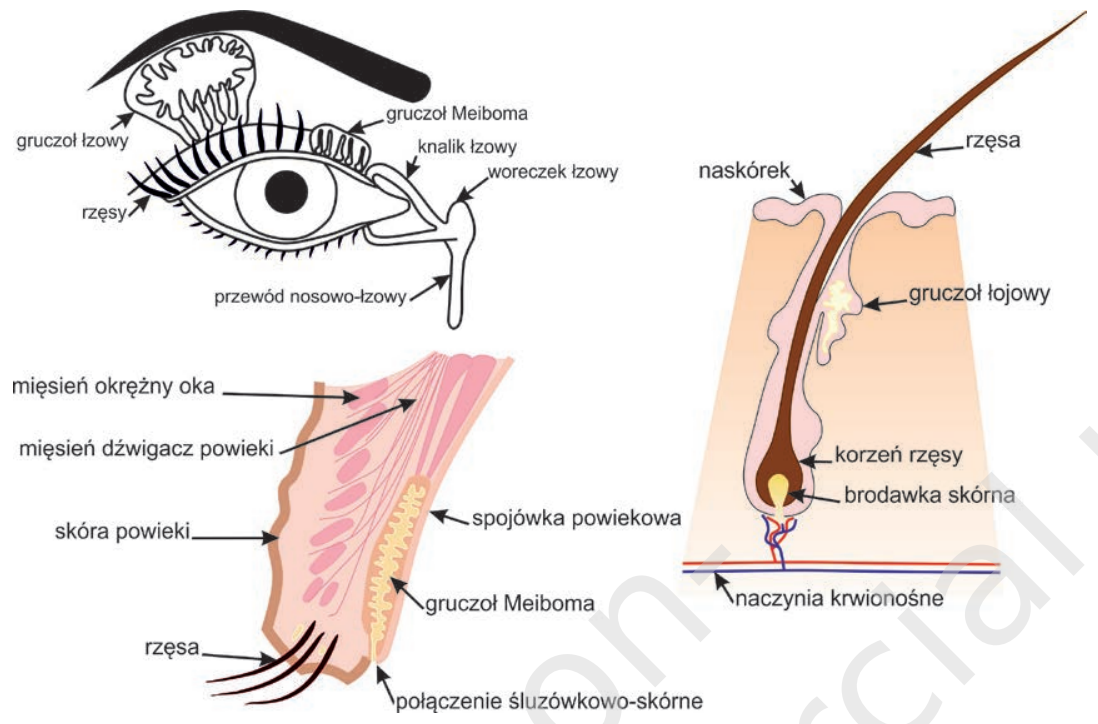

Czynnikiem predysponującym do MGD są schorzenia dermatologiczne, takie jak łojotokowe zapalenie skóry i trądzik różowaty $[10,6]$.

Doustna farmakoterapia izotretynoiną, stosowana w ciężkich postaciach trądziku pospolitego, sprzyja kolonizacji gronkowca złocistego w obrębie spojówek, powodując ZBP oraz ZSO [12].

Związek obecności nużeńca z ZBP został omówiony poniżej.

\section{ROLA NUŻEŃCA W PATOGENEZIE ZBP}

Za patogenezę zapalenia brzegów powiek u niektórych osób mogą odpowiadać bytujące w mieszkach włosowych lub gruczołach łojowych nużeńce - roztocza z rodzaju Demodex: Demodex folliculorum longus (w przednim) oraz Demodex folliculorum brevis (w tylnym). Ich obecność stwierdza się powszechnie, zwłaszcza u osób starszych, jednak $\mathrm{z}$ reguły nie powodują objawowego zapalenia. Sugerowano, że do rozwoju objawów może dochodzić w niektórych okolicznościach, jak przerost populacji nużeńca lub nadwrażliwość na przenoszone przez niego bakterie symbiotyczne [1]. Eradykacja nużeńca przynosiła poprawę u pacjentów z opornym ZBP [13]. Za objaw obecności nużeńca na powiekach uważa się walcowate złogi (kołnierzyki) u nasady rzęs [14]. Badania wykazały zależność nasilenia objawu dyskomfortu od liczby osobników Demodex przypadających na rzęsę [15]. Określenie roli nużeńca w patogenezie ZBP, a także trądziku różowatego (w którym obserwowano zwiększoną liczbę nużeńców [16]), wymaga dalszych badań.

Biorąc pod uwagę prawdopodobieństwo, że nużeniec jest wszechobecnym komensalem człowieka, Nicholls i wsp. postulują zmianę paradygmatu, przejście od eradykacji w stronę przywracania równowagi ekologicznej aparatu ochronnego oka. Bezobjawowa obecność nużeńca nie uzasadnia leczenia. Okuliści powinni mieć świadomość, że zaburzenie biocenozy powiek wskutek zbędnej terapii może spowodować przerost populacji bakterii, a poprzez usunięcie zapalnego bodźca wydzielania łez - doprowadzić do niedoboru ich wodnej składowej [17].
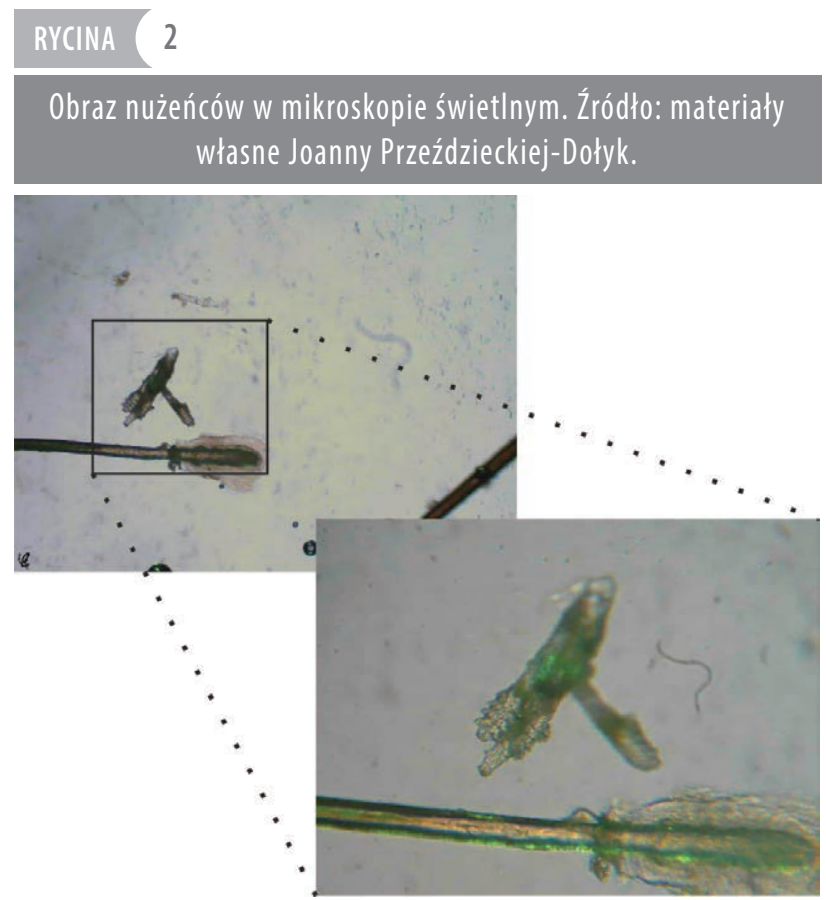


\section{ROZPOZNANIE}

Rozpoznanie ZBP opiera się na wywiadzie i stwierdzeniu charakterystycznych objawów w badaniu przy użyciu lampy szczelinowej. Pomocne mogą być dodatkowe badania, np.: posiewy z powiek i spojówek, dynamiczne obrazowanie gruczołów Meiboma oraz epilacja rzęs wykonywana w celu pobrania materiału do badania w mikroskopie świetlnym pod kątem obecności nużeńca.

\section{WYWIAD}

W ramach wywiadu dotyczącego historii choroby powinniśmy zapytać o:

- wystąpienie objawów, takich jak: zaczerwienienie, podrażnienie, pieczenie, łzawienie, swędzenie oczu, skorupienie i wypadanie rzęs, sklejenie powiek, widzenie obrazu rozmytego lub pływającego, nietolerancja soczewek kontaktowych, światłowstręt, częste mruganie, nawracające jęczmienie

- porę dnia - nasilenie się objawów rano wskazuje na ZBP, podczas gdy z nasilaniem się dolegliwości w późniejszych porach z reguły wiąże się zespół suchego oka (z niedoborem wodnej składowej łez)

- czas trwania objawów

- jedno- lub obustronna prezentacja objawów

- czynniki zaostrzające (np. dym, alergeny, wiatr, soczewki kontaktowe, suche powietrze, stosowanie retinoidów, dieta, alkohol, kosmetyki, praca przy komputerze, silne sztuczne światło)

- objawy związane z chorobami dermatologicznymi i ogólnymi (np. trądzik różowaty, atopowe zapalenie skóry, łuszczyca, przebyty półpasiec oczny, odrzucenie przeszczepu [GVHD, graft-versus-host disease])

- obecnie oraz wcześniej stosowaną farmakoterapię miejscową i ogólną (np. antyhistaminiki, antycholinergiki, czy wcześniejsze stosowanie leków mogących wpływać na powierzchnię oka, np. izotretynoiny)

- kontakt z osobą zarażoną pasożytami (np. wszą łonową - wszawica powiek).

Pytanie o przeszłość okulistyczną może dotyczyć szczegółów w zakresie przebytych zabiegów na gałce ocznej lub powiekach oraz wszelkiego rodzaju urazów. Stan po plastyce powiek ma istotne znaczenie, ponieważ może zwiększać powierzchnię ekspozycji i parowanie łez.

\section{BADANIE PRZEDMIOTOWE}

Badanie przedmiotowe dotyczące oka i jego przydatków obejmuje: pomiar najlepszej skorygowanej ostrości wzroku (BCVA, best-corrected visual acuity), badanie zewnętrzne, badanie przy lampie szczelinowej i pomiar ciśnienia wewnątrzgałkowego (CWG).
Przeprowadzane w warunkach dobrze oświetlonego pomieszczenia badanie zewnętrzne obejmuje oglądanie powiek, a także skóry okolicy policzkowej, czoła, nosa, brody i ewentualnie innych zajętych okolic. W trądziku różowatym stwierdza się typowe dla kolejnych stadiów choroby zmiany o charakterze:

- rumieniowym - początkowo przemijające zaczerwienienie twarzy, przechodzące w utrwalony rumień z obecnością licznych rozszerzeń naczyń (teleangiektazji)

- grudkowym i krostkowym - w tym okresie obok przetrwałego rumienia okresowo pojawiają się wykwity rumieniowo-grudkowo-krostkowe, z delikatnym złuszczaniem

- przerostowym - przerośnięte i zwłókniałe gruczoły łojowe, zapalne guzy i nacieki (phymata) w obrębie nosa, powiek, uszu, brody i czoła.

W ciężkich przypadkach powikłań ocznych: zapalenia spojówek, brzegów powiek lub nawet rogówki i tęczówki mówi się o odrębnej postaci - trądziku różowatym ocznym (ocular rosacea; ophthalmic rosacea) [18].

Zaburzenia powiek mogą dotyczyć ich pozycji (ectropion, entropion), niedomykalności, odruchu mrugania oraz wiotkości. Rzęsy oceniamy pod kątem wypadania, łamliwości lub zaburzenia kierunku wzrostu. Przy nasadach rzęs można zauważyć patologiczne złogi. Brzeg powieki może być zaczerwieniony lub zawierać przerastające naczynia krwionośne. Okiem nieuzbrojonym można stwierdzić występowanie: gradówek, jęczmieni, pęcherzy, owrzodzeń, łuszczenia naskórka czy bliznowacenia. Dokładniejsze badanie przydatków oka i filmu łzowego umożliwia lampa szczelinowa. Wszechstronnej ocenie specjalisty podlegają następujące elementy:

- film łzowy (menisk łzowy, wzór i czas przerwania filmu łzowego [TBUT, tear film break-up time], pienista wydzielina, złogi w filmie łzowym)

- przedni brzeg powieki (przekrwienie, teleangiektazje, bliznowacenie, zmiany pigmentowe, keratynizacja, owrzodzenie, pęcherze, podbarwione krwią złogi, gnidy P. pubis, walcowate mankiety: nużyca lub łojotok, złogi kosmetyków lub kołnierzyki naskórka)

- tylny brzeg powieki (nieprawidłowości ujść gruczołów Meiboma - takie jak: zaczopowanie, rozdęcie, cofnięcie, metaplazja, zanik; charakter wydzieliny gruczołowej - wyrazistość, gęstość, mętność, barwa; unaczynienie, keratynizacja, grudkowatość; pogrubienie; bliznowacenie/włóknienie)

- spojówka tarczkowa (po odwróceniu powieki): ocena gruczołów Meiboma pod kątem ich rozszerzenia i zapalenia, gradówki, rumień, bliznowacenie, keratynizacja, reakcja brodawkowa/pęcherzykowa, lipidowa wydzielina/zagęszczenia/złogi, zmiany bliznowate (zwłóknienie podnabłonkowe, skrócenie sklepienia, symblepharon przyrastanie powiek do gałki ocznej) 
- rogówka (ubytki nabłonka, punktowate ogniska po wybarwieniu fluoresceiną, różem bengalskim lub zielenią lizaminy (zasadniczo fluoresceiny używa się do oceny rogówki, a lizaminy - do oceny spojówki), obrzęk, nacieki, owrzodzenia i/lub blizny (drobne podnabłonkowe lub powierzchowne śródmiąższowe, okrężne, na średnim obwodzie rogówki, zazwyczaj niebarwiące się fluoresceiną), waskularyzacja, blizowacenie, w tym łuszczka, skrzydliki).

\section{BADANIA LABORATORYJNE}

Nie ma testów diagnostycznych specyficznych dla ZBP, ale w przypadku nawracającego, przedniego ZBP z dużym odczynem zapalnym oraz u pacjentów opornych na leczenie wskazane jest pobranie posiewów z brzegów powiek. Badanie mikroskopowe rzęs (po umieszczeniu na szkiełku podstawowym i dodaniu kropli fluoresceiny) może ujawnić obecność roztoczy z rodzaju Demodex [19]. Występowanie niepoddających się leczeniu zmian jednostronnych może wskazywać na etiologię nowotworową i wymaga diagnostyki w tym kierunku. W przypadkach przewlekłego ZBP opornego na standardowe leczenie, z towarzyszącymi cechami bliznowacenia spojówek, należy wziąć pod uwagę ocenę bioptatu z wykorzystaniem immunofluorescencji pod kątem pemfigoidu ocznego błon śluzowych (OMMP, ocular mucous membrane pemphigoid) [20].

Właściwa diagnoza i wdrożenie odpowiedniego leczenia pozwalają zmniejszyć objawy i dolegliwości, a w cięższych przypadkach zapobiec trwałemu uszkodzeniu i potencjalnej dysfunkcji widzenia. Ma to szczególne znaczenie u dzieci, ze względu na częste niezdiagnozowanie przewlekłego zapalenia powiek, rogówki i spojówek (BKC, blepharokeratoconjunctivitis) [21-25], które może występować jednostronnie i bywa mylone z zapaleniem herpetycznym. Na co jeszcze warto zwrócić uwagę? Znacznie krótszy czas przerwania filmu łzowego u pacjentów z MGD, nawet przy prawidłowym wydzielaniu wodnej składowej łez, świadczy o istotnej roli wydzieliny gruczołów Meiboma w utrzymaniu stabilności filmu łzowego [26]. Wytyczne Polskiego Towarzystwa Okulistycznego dotyczące diagnostyki i leczenia zespołu suchego oka z 2018 r. omawiają skale służące do oceny drożności gruczołów Meiboma oraz jakości ich wydzieliny. Zawierają również algorytm leczenia MGD w zależności od stadium zaawansowania choroby [27].

\section{DIAGNOSTYKA RÓŻNICOWA}

Zapalenie brzegów powiek i spojówek może być maską tocznia rumieniowatego krążkowego lub ocznego pemfigoidu błon śluzowych $[28,29]$. Właściwe powiązanie choroby przydatków oka z tymi schorzeniami układowymi umożliwi szybkie wdrożenie skutecznej terapii. Obraz ZBP, jak wspomniano, może maskować zmiany o podłożu nowotworowym. W takim przypadku wczesna diagnoza i leczenie mogą zapobiec zeszpeceniu pacjenta, a nawet zdecydować o jego życiu [8].

\section{LECZENIE}

Pacjent powinien mieć świadomość, że całkowite wyleczenie z choroby zazwyczaj nie jest możliwe. Poprawę przynieść mogą:

- stosowanie ciepłych okładów

- oczyszczanie powiek, w przypadku MGD - połączone $\mathrm{z}$ masażem powiek mającym ewakuować wydzielinę z gruczołów Meiboma lub z metodami spotencjalizowania odruchu wydzielniczego - np. IPL (intense pulsed light)

- antybiotykoterapia miejscowa i/lub ogólna

- miejscowe środki przeciwzapalne (np. glikokortykosteroidy, cyklosporyna).

Często stosuje się terapię łączoną. Higiena powiek jest zalecana zwłaszcza w przypadku zapalenia przedniego, natomiast terapia rozgrzewająca pomaga szczególnie w postaci tylnej zapalenia. Wypracowanie optymalnego schematu leczenia często odbywa się metodą prób i błędów i wymaga wytrwałości. Terapią pierwszego rzutu jest higiena powiek w połączeniu z ciepłymi okładami, realizowana na kilka sposobów [30].

\section{HIGIENA POWIEK}

Jedną z metod jest aplikacja ciepłych okładów na powieki przez kilka minut, aby zmiękczyć przylegający łupież i łuski lub wydzielinę oraz rozgrzać wydzielinę gruczołów Meiboma. Równomierne ciepło można uzyskać, stosując czyste ściereczki nasączone gorącą wodą z kranu, ogrzewacze dostępne w aptekach bez recepty lub wypełnione groszkiem/ ryżem poduszeczki do podgrzewania w kuchence mikrofalowej - zrobione własnoręcznie lub dostępne komercyjnie (np. zawierające pestki winogron). Bardzo ważne jest, by zawsze przestrzegać pacjentów przed używaniem zbyt gorących okładów, mogących oparzyć skórę, lub poinstruować, aby bardzo ciepłe okłady nakładali na gazik.

Oczyszczanie powiek można połączyć z krótkim i delikatnym masażem okrężnymi ruchami ku wewnątrz i zgodnie $\mathrm{z}$ anatomią ujść gruczołów. Dostępne komercyjnie chusteczki przeznaczone do higieny powiek zawierają kwas podchlorawy $0,01 \%$ i powodują silny efekt przeciwbakteryjny wykorzystywany w leczeniu przedniego ZBP. Masaż w kierunku prostopadłym do brzegu powiek przeprowadza się w celu wyciśnięcia wydzieliny gruczołów Meiboma. Przecieranie powiek wzdłuż ich brzegu usuwa gromadzącą się na rzęsach zaschniętą wydzielinę. Pacjent może 
oczyszczać nasady rzęs rozcieńczonym szamponem dla niemowląt (jedna część szamponu na cztery części wody) lub specjalistycznym płynem do higieny powiek naniesionym na płatek, kulkę bawełnianą lub czysty opuszek palca. W przypadku pacjentów o ograniczonej sprawności powyższe zabiegi mogą stanowić niebezpieczeństwo. Okulista powinien uwzględnić indywidualne możliwości pacjenta i dostosować do nich plan terapii. Również neurotroficzne zapalenie rogówki w wywiadzie wymaga szczególnej ostrożności, ze względu na ryzyko uszkodzenia nabłonka rogówkowego. Regularna higiena powiek, przeprowadzana

\section{RYCINA ( 3}

Standardowy schemat higieny brzegów powiek w trzech krokach. Źródło: materiały własne Michała Karaszewskiego.
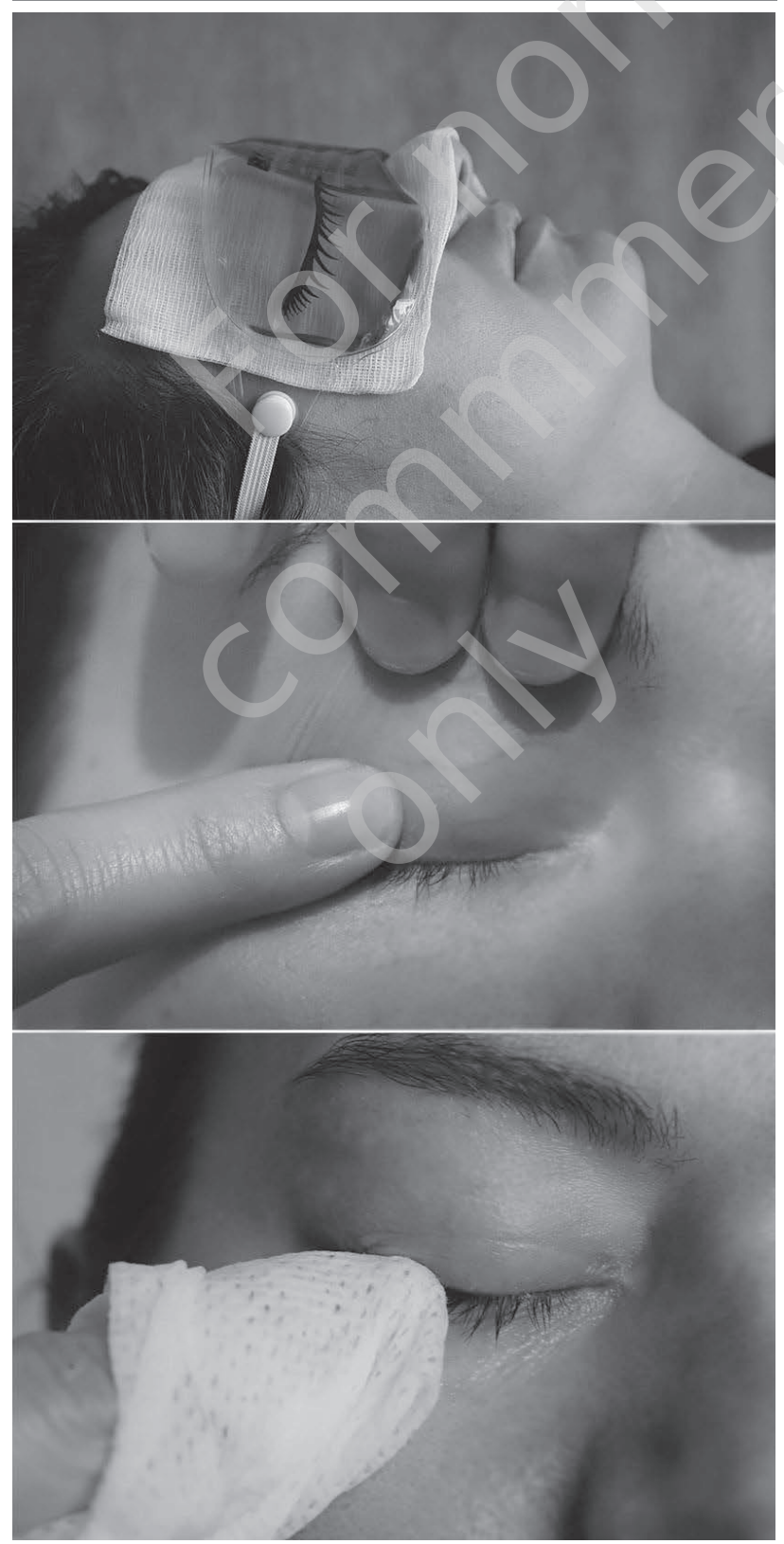

codziennie lub kilka razy w tygodniu, często pozwala wyciszyć objawy przewlekłego ZBP [8].

Okłady i masaż stosowane raz lub dwa razy dziennie w porze najbardziej dogodnej dla pacjenta są na ogół wystarczające. Wyciskanie zawartości gruczołów Meiboma może być szczególnie pomocne w MGD, ale powinno się je wykonywać z należytą ostrożnością. Częsta manipulacja w obrębie powiek może prowadzić do mechanicznego podrażnienia, a następnie przebudowy tkanek i bliznowacenia. W dodatku pacjenci cierpiący na zaawansowaną jaskrę, po operacjach filtracyjnych w wywiadzie, ale też dotychczas nieoperowani powinni być przestrzegani przed agresywnym uciskaniem powiek, które może prowadzić do wzrostu ciśnienia wewnątrzgałkowego. Stosowanie ciepłych kompresów w połączeniu z oczyszczaniem powiek należy zalecać pacjentom długoterminowo, ponieważ w przypadku przerwania terapii dochodzi do nawrotu objawów [8].

\section{ANTYBIOTYKOTERAPIA}

Antybiotykoterapia miejscowa przyczynia się do ograniczenia dolegliwości i skutecznie zmniejsza populację bakterii w przednim ZBP. Higiena powiek może jednak przynieść ulgę zarówno w przedniej, jak i tylnej postaci zapalenia. Nie ma jednoznacznych dowodów dotyczących skuteczności innych rodzajów terapii zapalenia brzegów powiek, takich jak miejscowa glikokortykosteroidoterapia czy doustna antybiotykoterapia [31]. Maści oczne z bacytracyną lub erytromycyną mogą być zalecane i aplikowane na powieki przez kilka tygodni, raz lub kilka razy w ciągu dnia albo przed snem. Antybiotykoterapię miejscową można powtarzać z zachowaniem przerw i wykorzystaniem różnych rodzajów leków, by zapobiec rozwinięciu się oporności [8].

O częstotliwości i czasie trwania terapii powinny decydować ciężkość zapalenia i odpowiedź na leczenie. Kliniczna skuteczność stosowanej miejscowo zawiesiny tobramycyny $\mathrm{z}$ deksametazonem lub azytromycyny w postaci o przedłużonym uwalnianiu została oceniona w niekontrolowanym badaniu off-label, sponsorowanym przez producenta. Wydają się one redukować niektóre z objawów zapalenia brzegów powiek [32-34]. Tetracykliny w postaci doustnej oraz antybiotyki miejscowe mogą być pomocne u pacjentów z przewlekłymi dolegliwościami, nieustępującymi po samej higienie powiek połączonej z masażem gruczołów Meiboma. Doksycyklina, minocyklina lub tetracyklina może być przyjmowana raz dziennie i odstawiana po zauważeniu poprawy klinicznej. Alternatywnie zaleca się doustną erytromycynę lub azytromycynę, szczególnie u kobiet w wieku rozrodczym i u dzieci. Tetracykliny i makrolidy wykazują również aktywność przeciwzapalną i redukują przebudowę tkanek (co w tej lokalizacji wydaje się korzystnym działaniem). Terapia może być przerywana i wznawiana w zależności od ciężkości ZBP i tolerancji farmakoterapii. Zasad- 
ność użycia tetracyklin opiera się po części na niewielkich próbach klinicznych, które donoszą o skuteczności leków u pacjentów z trądzikiem różowatym ocznym i przedłużeniu czasu przerwania filmu łzowego u pacjentów z trądzikiem różowatym i MGD. Tetracykliny obniżają produkcję lipaz zarówno przez S. epidermidis, jak i S. aureus. Mogą też wywoływać: fotosensytyzację, zaburzenia żołądkowojelitowe, zapalenie pochwy, i - rzadziej - azotemię [8].

Antybiotyki z grupy tetracyklin są jednym z czynników ryzyka pseudoguza mózgu, czyli idiopatycznego nadciśnienia śródczaszkowego (IIH, idiopathic intracranial hypertension). Ich metabolizm może zaburzać działanie określonych substancji, np. zmniejszać skuteczność doustnej antykoncepcji i nasilać działanie warfaryny. Stosowanie doksycykliny w postaci o przedłużonym uwalnianiu może redukować jej efekty uboczne. Tetracykliny są przeciwwskazane u kobiet ciężarnych, karmiących piersią i u pacjentów, u których w przeszłości wystąpiła nadwrażliwość na tetracykliny. Tetracykliny nie powinny być również stosowane u dzieci poniżej 8. r.ż., gdyż mogą powodować wybarwienie zębów, ale można je zastąpić doustną erytromycyną. Minocyklina, według doniesień, może wybarwiać skórę, paznokcie, twardówkę, spojówki, zęby, język i kości [8].

Doustna azytromycyna była $\mathrm{z}$ powodzeniem stosowana off-label w leczeniu trądziku różowatego, jako alternatywa doustnych tetracyklin, zwłaszcza w połączeniu z miejscową podażą takrolimusu $0,1 \%$. Podobnie doustna azytromycyna w dawce $500 \mathrm{mg} / 24 \mathrm{~h}$ przez $3 \mathrm{dni}$, w trzech cyklach z 7-dniowymi przerwami wykazała dobrą odpowiedź kliniczną u 13 pacjentów z ZBP $\mathrm{w}$ prospektywnym jednoośrodkowym badaniu otwartym. Należy zwrócić uwagę, że w badaniach $w$ Tennessee wykazano niewielki, lecz absolutny wzrost w liczbie zgonów sercowo-naczyniowych [35], który szczególnie zaznaczył się wśród pacjentów z wysokim podstawowym ryzykiem choroby sercowo-naczyniowej leczonych doustną azytromycyną przez 5 dni. W marcu $2013 \mathrm{r}$. FDA wydała ostrzeżenie, że doustna azytromycyna może prowadzić do zaburzeń czynności elektrycznej serca i wywołać poważne zaburzenia rytmu serca.

W badaniach wykazano, że miejscowe i ogólne stosowanie iwermektyny eliminowało lub zmniejszało liczebność nużeńca Demodex folliculorum, oznaczanego na epilowanych rzęsach od pacjentów z ZBP lub trądzikiem różowatym [36]. Należałoby przeprowadzić dodatkowe badania, aby określić skuteczność miejscowego metronidazolu, doustnej tetracykliny, minocykliny w małej dawce lub miejscowo podawanej cyklosporyny w postaci ocznej trądziku różowatego.

\section{GLIKOKORTYKOSTEROIDOTERAPIA}

Krótkotrwała terapia glikokortykosteroidami podawanymi miejscowo może być pomocna w zapaleniach powiek lub powierzchni gałki ocznej, takich jak: ciężkie zapale- nie infekcyjne spojówek, zapalenie brzeżne rogówki albo pryszczyk. Glikokortykosteroidy w postaci kropli lub maści aplikuje się zwykle kilka razy dziennie na powierzchnię oka. Po wyciszeniu się stanu zapalnego można stopniowo zmniejszać dawkę glikokortykosteroidu lub go odstawić, a następnie podawać sporadycznie, by utrzymać komfort pacjenta [8].

Glikokortykosteroidy powinno się ordynować w najmniejszej skutecznej dawce i w miarę możliwości unikać długotrwałej terapii. Pacjenci powinni być informowani o potencjalnych skutkach ubocznych glikokortykosteroidów, zwłaszcza o ryzyku zwiększenia ciśnienia wewnątrzgałkowego (steroid responder) lub rozwoju zaćmy. Aby zminimalizować efekty uboczne, można stosować substancje o wysokiej swoistości miejsca wiązania, takie jak etabonian loteprednolu, lub o ograniczonej penetracji ocznej, jak fluorometolon [8].

\section{MODYFIKACJA DIETY}

Modyfikacja diety to tradycyjny, choć słabo udokumentowany sposób leczenia trądziku różowatego. Rola suplementacji diety egzogennymi kwasami tłuszczowymi w leczeniu ZBP poddana została ocenie w rocznym badaniu, w którym pacjenci przyjmowali olej lniany w dawce po 2 kapsułki $1000 \mathrm{mg} 3$ razy dziennie. W grupie pacjentów zażywających suplement odnotowano wydłużenie czasu przerwania filmu łzowego i poprawę w skali wydzieliny gruczołów Meiboma (Meibum score), co potwierdziło potencjalną korzyść takiego leczenia u niektórych pacjentów z ZBP. W prospektywnym, wieloośrodkowym, podwójnie zaślepionym badaniu, sponsorowanym przez National Eye Institute i National Institutes of Health, oceniono użycie doustnych suplementów kwasów omega-3 wśród pacjentów ze średnio nasilonym do ciężkiego ZSO. W grupie losowo wybranych pacjentów, w której suplementowano kwasami tłuszczowymi omega-3 przez rok, nie wykazano istotnie lepszych wyników w porównaniu z grupą placebo. Te dwa przeciwstawne wyniki mogą odzwierciedlać różnice w populacji pacjentów, postaciach farmakologicznych suplementów, dawce i/lub samym procesie chorobowym lub stadium choroby, w którym je stosowano, np. w ZBP albo w umiarkowanej do ciężkiej postaci ZSO. Potrzeba dalszych badań, aby jednoznacznie określić rolę kwasów omega-3 w chorobie powierzchni oka $[37,38]$.

\section{POSTĘPOWANIE POMOCNICZE}

Ze względu na występującą u wielu pacjentów z ZBP niestabilność filmu łzowego stosowanie sztucznych łez może przynieść poprawę, jeśli jest uzupełnieniem oczyszczania powiek i leczenia farmakologicznego. W przypadku stosowania sztucznych łez częściej niż 4 razy dziennie powinno 
się użyć kropli bez konserwantów, aby uniknąć związanej z nimi toksyczności. Miejscowa cyklosporyna i/lub zatyczki do punktów łzowych mogą być pomocne w leczeniu współistniejącego niedoboru wodnej składowej łez [39]. W badaniu obejmującym 33 dorosłych pacjentów z MGD w grupie poddanej terapii miejscową cyklosporyną 0,05\% wykazano redukcję liczby zaczopowanych ujść gruczołów Meiboma po 3 miesiącach, nie odnotowano jednak istotnej statystycznie poprawy w zakresie objawów podmiotowych [40]. Stosowanie zatyczek do punktów łzowych oraz innych metod leczenia w różnych subpopulacjach chorych z ZSO omawiają interdyscyplinarne wytyczne polskich towarzystw naukowych z 2019 r. pt. Zapobieganie i leczenie ciężkiego zapalenia rogówki w przebiegu zespołu suchego oka [41].

\section{POSTĘPOWANIE W RAZIE NIESKUTECZNOŚCI LECZENIA}

U pacjentów nieodnoszących korzyści w wyniku stosowania powyższych metod leczenia należy wziąć pod uwagę zakażenie nużeńcem - demodekozę powiek. Poprawa w zakresie objawów i zmniejszenie dolegliwości były niedawno raportowane w wynikach badań prowadzonych na niewielkiej próbie, w grupie pacjentów opornych na wcześniej wymienione metody leczenia, w której przez co najmniej 6 tygodni stosowano chusteczki do powiek z 50\% olejkiem drzewa herbacianego raz w tygodniu oraz codzienną higienę brzegów powiek i twarzy przy użyciu szamponu z wyciągiem drzewa herbacianego. W niektórych przypadkach opornej nużycy powiek korzystna okazała się również doustna iwermektyna [36]. Pacjentów z nietypowym ZBP lub nieodpowiadających na farmakoterapię należy ponownie poddać dokładnej ocenie, podejrzewając guza powieki. Stwierdzenie takich cech, jak: masa guzkowa, owrzodzenie, wydatne bliznowacenie, utrata rzęs, miejscowe skorupowacenie, łuszczenie naskórka, lub żółte guzki spojówkowe otoczone intensywnym zapaleniem - może wskazywać na obecność zmiany nowotworowej. Rak podstawnokomórkowy i rak kolczystokomórkowy są najczęściej spotykanymi guzami występującymi w obrębie powiek. Melanoma i rak gruczołu łojowego to następne najczęściej diagnozowane guzy powieki [42]. Rak gruczołu łojowego może stanowić trudność diagnostyczną, ze względu na możliwy wieloogniskowy początek i ciężkie zapalenie spojówek związane z rozrostem pagetoidalnym. Powinno się wziąć go pod uwagę w przypadku starszych pacjentów z przewlekłym, jednostronnym, opornym zapaleniem powieki lub spojówki albo nawracającymi gradówkami [8].

\section{ROZWIJANE METODY LECZENIA}

Alternatywnie lub jako uzupełnienie samodzielnie stosowanej przez pacjentów higieny powiek mogą być zalecane zabiegi z wykorzystaniem nowych, specjalistycznych technik i urządzeń.
W leczeniu dostępne są procedury zabiegowe mające w założeniu prowadzić do odblokowania zaczopowanych ujść gruczołów Meiboma, przy użyciu IPL lub środków mechanicznych (np. mikroblefaroeksfoliacja brzegu powieki, sondowanie gruczołów Meiboma i/lub urządzenia termopulsacyjne). Chociaż wykonano badania sponsorowane, powinno się przeprowadzić niezależne maskowane próby kliniczne, aby ocenić skuteczność tych kosztownych, pierwotnie odpłatnych procedur leczniczych. Sondowanie gruczołów Meiboma to procedura, którą można przeprowadzić przy lampie szczelinowej lub w warunkach małej sali zabiegowej. Zabieg jest względnie bezpieczny, choć inwazyjny i wymagający odpowiedniego znieczulenia. Sponsorowany przegląd retrospektywny obejmujący 25 pacjentów wykazał, że śródkanalikowe sondowanie gruczołów Meiboma zapewniało trwałe i szybkie ustąpienie objawów u pacjentów z niedrożnością gruczołów Meiboma. Wektorowa pulsacja termiczna VTP (vector thermal pulsation) to wykorzystywana w terapii gruczołów Meiboma technologia zaprojektowana do transferu ciepła, która w aktywny sposób wyciska zawartość gruczołów Meiboma. Dostępne komercyjnie urządzenie aplikuje ciepło o temperaturze $42,5^{\circ} \mathrm{C}$ na wewnętrzną powierzchnię powieki przy zabezpieczeniu rogówki, a pulsacyjny nacisk jest wywierany na zewnętrzną stronę powieki. Wielokrotne badania sponsorowane pokazały, że pojedyncza terapia VTP może być pomocna w poprawie funkcji gruczołów Meiboma i redukcji objawów zespołu suchego oka na rok (albo dłużej) po zabiegu [43, 44]. Dotychczas nie przeprowadzono niezależnych badań, które by potwierdzały doniesienia pochodzące z badań sponsorowanych lub im przeczyły.

Mikroblefaroeksfoliacja może być prowadzona w gabinecie przy użyciu dostępnych komercyjnie urządzeń, składających się z jednostki trzymanej w dłoni oraz jednorazowej gąbki, która szybko wiruje, by zapewnić oczyszczenie i złuszczenie naskórka brzegu powieki. Dostępne są limitowane, pierwotne, sponsorowane raporty porównujące te techniki z tradycyjnym manualnym peelingiem powiek. Murphy i wsp. donosili, że higiena powiek z użyciem olejku drzewa herbacianego w połączeniu z mikroblefaroeksfoliacją przynosiła korzyść podobną jak w przypadku stosowania samej tylko higieny powiek $\mathrm{z}$ użyciem olejku drzewa herbacianego - u pacjentów z ZBP wtórnym do zakażenia nużeńcem [45].

Intensywne światło pulsacyjne jest to rozbieżna wiązka światła z szerokim spektrum fali od 500 do $1200 \mathrm{~nm}$, mająca szerokie zastosowanie w celach estetycznych i terapeutycznych w dermatologii. Jest to też nowa, obiecująca terapia w MGD. Efekt fototermiczny pomaga zmniejszyć zapalenie gruczołu, ale dokładny mechanizm działania pozostaje niejasny. Kilka grup donosiło, że terapia IPL poprawiała funkcję gruczołów Meiboma i makro- oraz mikrostrukturę gruczołów, z wtórną poprawą w zakresie objawów ZSO. 
W niewielkim niezależnym badaniu na 28 pacjentach wykazano poprawę objawów i jakości filmu łzowego w porównaniu z drugim okiem. Ta dosyć droga procedura nie jest objęta refundacją. Aby osiągnąć długotrwałe efekty, powinna być powtarzana [8]. Choć udowodniono skuteczność IPL w leczeniu teleangiektazji, nie ma wystarczających dowodów skutecznego działania w przypadkach trądziku różowatego [46].

\section{PODSUMOWANIE}

Zapalenie brzegów powiek to złożony, istotny i powszechny problem okulistyczny, którego oddziaływanie zdrowotne może być porównane do tak poważnej choroby oczu, jaką jest jaskra. Chociaż w przypadku ZBP rzadko dochodzi do równie dramatycznego uszkodzenia funkcji widzenia jak w wyniku uszkodzenia nerwów wzrokowych, to zachodzące zmiany mogą być nieodwracalne, jeśli w porę nie zostanie wdrożone odpowiednie leczenie. Istotna jest wczesna diagnostyka i odpowiednia terapia, wymagająca od pacjenta znacznego i długotrwałego zaangażowania, a od lekarzy okulistów - dobrego przygotowania teoretycznego i znajomości dostępnych procedur. Etiologia i patogeneza schorzenia są zróżnicowane, wymagają dalszego poznania, a znaczenie infestacji nużeńcem wydaje się czasem przejaskrawione $\mathrm{w}$ materiałach prasowych czy reklamowych coraz to liczniejszych producentów preparatów do higieny brzegów powiek.

Chociaż nie ma mocnych dowodów na istnienie skutecznej terapii przewlekłego ZBP, wykazano, że określone rodzaje terapii mogą zapewnić poprawę w zakresie objawów. Poprawa w zakresie przedmiotowych i podmiotowych objawów ZBP może prowadzić do zmniejszenia liczby wizyt w gabinecie i do wzrostu wydajności leczenia, co z kolei może skutkować spadkiem kosztów bezpośrednich i pośrednich oraz poprawą jakości życia pacjentów. Procedury gabinetowe, jak: mikroblefaroeksfoliacja, pulsacja termiczna gruczołów Meiboma oraz IPL, nie są refundowane, mogą więc narazić pacjenta na znaczne koszty.

Prawdopodobnie zapalenie brzegów powiek stanowi istotny ciężar dla publicznej ochrony zdrowia i społeczeństwa, przyczynia się również do obniżenia jakości życia pacjentów. Aby dokładnie określić ten wpływ, a także udział poszczególnych procedur leczniczych w jego redukcji, potrzebne są dodatkowe badania. Przewlekły charakter schorzenia, a także schematy leczenia wymagające znacznego zaangażowania pacjenta $\mathrm{w}$ procesie leczniczym skłaniają do poszukiwania rozwiązań i usprawnień, być może wśród koncepcji rozwijanych w duchu patient empowerment. Edukacja, uświadamianie i przebudowa relacji lekarz-pacjent $\mathrm{w}$ stronę współtwórczego partnerstwa sprzyjają aktywności pacjenta, dzięki czemu przyczyniają się do skuteczności terapii i skrócenia czasu jej trwania, a także redukcji odczuwanych przez niego uciążliwości zaleceń. Pozwoliłyby zatem zredukować obciążenie systemów ochrony zdrowia [47].

Źródto rycin: Wszystkie ryciny pochodza z materiatów wtasnych autoralautorów.

\section{ADRES DO KORESPONDENCJI \\ lek. Michał Karaszewski \\ 53-111 Wrocław, ul. Ślężna 96/16 \\ e-mail:michal.karaszewski@student.umed.wroc.pl}

\section{ORCID}

Michał Karaszewski - ID - http://orcid.org/0000-0003-0778-0938 Marta Misiuk-Hojło - ID - http://orcid.org/0000-0002-4020-3203 Joanna Przeździecka-Dołyk - ID - http://orcid.org/0000-0002-1099-4876 Jan Gnus - ID - http://orcid.org/0000-0002-6220-950X

\section{Piśmiennictwo}

1. Bowling B. Eyelids. In: Kanski's Clinical Ophthalmology. 2016.

2. Soh Qin R, Tong Hak Tien L. Healthcare delivery in meibomian gland dysfunction and blepharitis. Ocul Surf. 2019; 17(2): 176-8.

3. The Definition and Classification of Dry Eye Disease: Report of the Definition and Classification Subcommittee of the International Dry Eye Workshop (2007). Ocul Surf. 2007; 5(2): 75-92.

4. Arita R, Itoh K, Inoue K et al. Noncontact Infrared Meibography to Document Age-Related Changes of the Meibomian Glands in a Normal Population. Ophthalmology. 2008; 115(5): 911-5.

5. Lemp MA, Nichols KK. Blepharitis in the United States 2009: A survey-based perspective on prevalence and treatment. Ocul Surf. 2009; $7(2$ suppl): S1.

6. Schaumberg DA, Nichols JJ, Papas EB et al. The international workshop on meibomian gland dysfunction: Report of the subcommittee on the epidemiology of, and associated risk factors for, MGD. Investig Ophthalmol Vis Sci. 2011; 52(4): 1994-2005.

7. Stanek S. Meibomian gland status comparison between active duty personnel and U.S. veterans. Mil Med. 2000; 165(8): 591-3.

8. Amescua G, Akpek EK, Farid M et al. Blepharitis Preferred Practice Pattern ${ }^{\oplus}$. Ophthalmology. 2018; 126: P56-93.

9. Bowman RW, Dougherty JM, McCulley JP. Chronic blepharitis and dry eyes. Int Ophthalmol Clin. 1987; 27(1): 27-35. 
10. McCulley JP, Dougherty JM, Deneau DG. Classification of chronic blepharitis. Ophthalmology. 1982; 89(10): 1173-80.

11. Baum J. Clinical manifestations of dry eye states. Trans Ophthalmol Soc U K. 1985; 104 (Pt 4): 415-23.

12. Bozkurt B, Irkeç MT, Atakan N et al. Lacrimal function and ocular complications in patients treated with systemic isotretinoin. Eur J Ophthalmol. 2002; 12(3): 173-6.

13. Arici MK, Sümer Z, Toker Ml et al. The prevalence of Demodex folliculorum in blepharitis patients and the normal population. Ophthalmic Epidemiol. 2005; 12(4): 287-90.

14. Gao YY, Di Pascuale MA, Li W et al. High prevalence of Demodex in eyelashes with cylindrical dandruff. Investig Ophthalmol Vis Sci. 2005; 46(9): 3089-94.

15. Koo H, Kim TH, Kim KW et al. Ocular surface discomfort and demodex: Effect of tea tree oil eyelid scrub in demodex blepharitis. J Korean Med Sci. 2012; 27(12): 1574-9.

16. Deeks ED. Ivermectin: A Review in Rosacea. Am J Clin Dermatol. 2015; 16(5): 447-52.

17. Nicholls SG, Oakley CL, Tan A et al. Demodex species in human ocular disease: new clinicopathological aspects. Int Ophthalmol. 2017; 37(1): 303-12.

18. Plewig G, Kligman AM. ACNE and ROSACEA. Berlin, Heidelberg: Springer Berlin Heidelberg; 2000.

19. Kheirkhah A, Blanco G, Casas V et al. Fluorescein dye improves microscopic evaluation and counting of Demodex in blepharitis with cylindrical dandruff. Cornea. 2007; 26(6): 697-700.

20. Conjunctivitis PPP - 2018 - American Academy of Ophthalmology. https://www.aao.org/preferred-practice-pattern/conjunctivitis-ppp-2018.

21. Jones SM, Weinstein JM, Cumberland P et al. Visual Outcome and Corneal Changes in Children with Chronic Blepharokeratoconjunctivitis. Ophthalmology. 2007; 114(12): 2271-80.

22. Hammersmith KM, Cohen EJ, Blake TD et al. Blepharokeratoconjunctivitis in children. Arch Ophthalmol. 2005; 123, $1667-70$.

23. Donaldson KE, Karp CL, Dunbar MT. Evaluation and treatment of children with ocular rosacea. Cornea. 2007; 26(1): 42-6.

24. Çetinkaya A, Akova YA. Pediatric Ocular Acne Rosacea: Long-Term Treatment With Systemic Antibiotics. Am J Ophthalmol. 2006; 142(5): 816-21.

25. Viswalingam M, Rauz S, Morlet $\mathrm{N}$ et al. Blepharokeratoconjunctivitis in children: diagnosis and treatment. Br J Ophthalmol. 2005; 89(4): 400-3.

26. Pflugfelder SC, Tseng SCG, Sanabria O et al. Evaluation of subjective assessments and objective diagnostic tests for diagnosing tearfilm disorders known to cause ocular irritation. Cornea. 1998; 17: 38-56.

27. Grabska-Liberek I, Mrukwa-Kominek E, Szaflik J et al. Wytyczne Polskiego Towarzystwa Okulistycznego dotyczące diagnostyki i leczenie Zespołu Suchego Oka. 2018: 9-10, 12. https:/www.pto.com.pl/storage/guidelines/35/714c0222f3d8edfaf6e4b2ab89e4e34a.pdf.

28. Acharya N, Pineda R, Uy HS et al. Discoid Lupus Erythematosus Masquerading as Chronic Blepharoconjunctivitis. Ophthalmology. 2005; 112(5): e19-23.

29. Diaz-Valle D, Benitez Del Castillo JM, Fernandez Aceñero MJ et al. Bilateral lid margin ulcers as the initial manifestation of crohn disease. Am J Ophthalmol. 2004; 138(2): 292-4.

30. Key JE. A comparative study of eyelid cleaning regimens in chronic blepharitis. CLAO J. 1996; 22(3): 209-12.

31. Lindsley K, Matsumura S, Hatef E et al. Interventions for chronic blepharitis. Cochrane Database Syst Rev. 2012; (5): CD005556.

32. Foulks GN, Borchman D, Yappert M et al. Topical azithromycin therapy for meibomian gland dysfunction: Clinical response and lipid alterations. Cornea. 2010; 29(7): 781-8.

33. Haque RM, Torkildsen GL, Brubaker K et al. Multicenter open-label study evaluating the efficacy of azithromycin ophthalmic solution $1 \%$ on the signs and symptoms of subjects with blepharitis. Cornea. 2010; 29(8): 871-7.

34. Torkildsen GL, Cockrum P, Meier E et al. Evaluation of clinical efficacy and safety of tobramycin/dexamethasone ophthalmic suspension 0.3/0.05 compared to azithromycin ophthalmic solution 1 in the treatment of moderate to severe acute blepharitis/blepharoconjunctivitis. Curr Med Res Opin. 2011; 27(1): 171-8.

35. Ray WA, Murray KT, Hall K et al. Azithromycin and the risk of cardiovascular death. N Engl J Med. 2012; 366(20): 1881-90.

36. Nogueira Filho PA, Hazarbassanov RM, Grisolia ABD et al. The efficacy of oral ivermectin for the treatment of chronic blepharitis in patients tested positive for Demodex spp. Br J Ophthalmol. 2011; 95: 893-5.

37. Asbell PA, Maguire G, Pistilli M et al. n-3 Fatty acid supplementation for the treatment of dry eye disease. N Engl J Med. 2018; 378(18): 1681-90.

38. Macsai MS. The role of omega-3 dietary supplementation in blepharitis and meibomian gland dysfunction (An AOS thesis). Trans Am Ophthalmol Soc. 2008; 106: 336-56.

39. Jones L, Downie LE, Korb D et al. TFOS DEWS II Management and Therapy Report. Ocul Surf. 2017; 15(3): 575-628.

40. Perry HD, Doshi-Carnevale S, Donnenfeld ED et al. Efficacy of commercially available topical cyclosporine A $0.05 \%$ in the treatment of meibomian gland dysfunction. Cornea. 2006; 25(2): 171-5.

41. Dobrowolski D, Gil L, Grabska-Liberek l et al. Zapobieganie i leczenie ciężkiego zapalenia rogówki w przebiegu zespołu suchego oka. Wytyczne PTO, PTR, PTHiT. 2019. http://pto.com.pl/wytyczne.

42. Margo CE, Mulla ZD. Malignant tumors of the eyelid: A population-based study of non-basal cell and non-squamous cell malignant neoplasms. Arch Ophthalmol. 1998; 116(2): 195-8. 
43. Blackie CA, Coleman CA, Holland EJ. The sustained effect (12 months) of a single-dose vectored thermal pulsation procedure for meibomian gland dysfunction and evaporative dry eye. Clin Ophthalmol. 2016; 10: 1385-96.

44. Greiner J V. Long-term (12-month) improvement in meibomian gland function and reduced dry eye symptoms with a single thermal pulsation treatment. Clin Exp Ophthalmol. 2013; 41(6): 524-30.

45. Murphy O, O'Dwyer V, Lloyd-McKernan A. The efficacy of tea tree face wash, 1, 2-Octanediol and microblepharoexfoliation in treating Demodex folliculorum blepharitis. Contact Lens Anterior Eye. 2018; 41(1): 77-82.

46. van Zuuren EJ, Fedorowicz Z, Carter B et al. Interventions for rosacea. Vol. 2017, Cochrane Database Syst Rev. John Wiley and Sons Ltd; 2015: 83.

47. Palumbo R. The bright side of patient empowerment. In: SpringerBriefs in Public Health. 2017.

\section{Wkład autorów:}

Michał Karaszewski: idea pracy, tekst główny;

Marta Misiuk-Hojto: konsultacja merytoryczna;

Joanna Przeździecka-Dołyk: korekta merytoryczna, przygotowanie ilustracji;

Jan Gnus: konsultacja części Podsumowanie.

Konflikt interesów:

Nie występuje.

Finansowanie:

Nie występuje.

Etyka:

Treści przedstawione w artykule sa zgodne z zasadami Deklaracji Helsińskiej,

dyrektywami EU oraz ujednoliconymi wymaganiami dla czasopism biomedycznych.
Authors' contributions:

Michał Karaszewski: idea of work, main text;

Marta Misiuk-Hojło: substantive consultation;

Joanna Przeździecka-Dołyk: substantive correction, preparation of illustrations; Jan Gnus: consultation of the Summary part.

Conflict of interest:

None.

Financial support:

None.

Ethics:

The content presented in the article complies with the principles of the Helsinki Declaration, EU directives and harmonized requirements for biomedical journals. 